\title{
Detection of hepatitis C virus RNA by in situ hybridization in paraformaldehyde fixed biopsies
}

\author{
HS Carvalho/ ${ }^{+}$, ML Baptista, MA Pinto, M Silva, CM Takiya*, V Chagas**, V Pannain**, \\ HSM Coelho***, CFT Yoshida
}

\author{
Departamento de Virologia, Instituto Oswaldo Cruz-Fiocruz, Av. Brasil 4365, 21045-900 Rio de Janeiro, RJ, Brasil \\ * Departamento de Histologia, CCS/UFRJ, Rio de Janeiro, RJ, Brasil **Departamento de Patologia, Serviço de Anatomia \\ Patológica ***Departamento de Clinica Médica, Setor de Gastroenterologia, Hospital Universitário Clementino Fraga Filho, \\ UFRJ, Rio de Janeiro, RJ, Brasil
}

Fourteen hepatitis $C$ virus (HCV) chronically infected patients were submitted to routine liver biopsy for histological evaluation. Liver samples were assayed to HCV-RNA by in situ hybridization, using digoxigenin labeled probe. HCV genotypes were found to be predominantly type 1 (71.4\%), followed by genotype 3 (21.4\%), and genotype $2(7.2 \%)$. Alanine-aminotransferase levels were raised in 10 patients. The histopathological scores were minimal (21.4\%), mild (57.2\%), and moderate (21.4\%). Viral RNA was detected in liver cells from nine patients (64.3\%). ISH method provides localization and poor confirmation of HCV RNA in the liver tissue of HCV chronic patients.

Key words: hepatitis C virus RNA - in situ hybridization - liver biopsy - chronic hepatitis - viral hepatitis

In situ hybridization (ISH) technique was initially introduced in 1969 (John et al. 1969, Pardue \& Gall 1969) for the localization of DNA sequences, after 20 years Macville described non-radioactive protocol to detect mRNA transcripts in different tissues (Macville et al. 1995). Currently the diagnosis is based on specific antibody detection (antihepatitis $\mathrm{C}$ virus - anti-HCV) in serum and several nucleic acid-based technology are undertaken to detect the prevalence of circulating virus genome (Schiff et al. 1999). The detection of virus genome and viral protein in liver sections, is an additional diagnostic procedure (Walker et al. 1998). Nevertheless, the detection and exact localization of the HCV genome in the liver and in the other tissues may have a key role to understanding the pathogenesis and natural history of HCV infection (Qian et al. 2004). The aim of the present study was to establish a method for HCV RNA detection using in situ molecular hybridization in liver biopsies of chronically infected patients. Moreover, we investigated possible correlation between the presence of HCV in liver and histological, biochemical, serological, and molecular information. In this work, 14 HCV chronically infected patients (10 male and 4 female) who attended at the Liver Clinic, Hospital Universitário Clementino Fraga Filho/Federal University of Rio de Janeiro (RJ, Brazil) were investigated, which they were submitted to liver biopsies before starting antiviral therapy. All individuals were known to be positive for anti-HCV antibodies and for HCV RNA in serum. The mean age of male patients was $45( \pm 13.7)$ years and of female patients was

Financial support: Faperj, $\mathrm{CNPq}$

Corresponding author. E-mail: hustenc@ hotmail.com

Received 6 December 2004

Accepted 20 April 2005
$53( \pm 6.2)$ years. Exclusion criteria included the presence of coagulation disorders, HIV seropositivity, co-infection of hepatitis B and D virus, autoimmune hepatitis, alcoholic liver disease or any kind of drug use. The procedures protocol was submitted to the Human Research Committee of the Federal University of Rio de Janeiro and reviewed by the Institutional Reviewer Board. Liver specimens were divided in two samples: one for histological evaluation, which was fixed in 10\% buffered formalin, and the other, designated to the ISH, was fixed in 4\% paraformaldehyde/ PBS. Both fragments were included in paraffin further, sectioned into $4 \mu \mathrm{m}$ thickness pieces and fixed on silane-coated slides. The criteria adopted to determine the histological activity index was previously described (Ishak et al. 1995). Peripheral blood $(10 \mathrm{ml})$ was collected from each patient to evaluate the biochemical liver function and also to confirm $\mathrm{HCV}$ serological and molecular status at the moment of the liver biopsy. Anti-HCV was tested using enzyme immunoassay UBI ${ }^{\circledR}$ HCV-EIA 4,0 (United Biochemical Inc., US). Supplemental testing was also carried out using an immunoblot assay, Lia-Tek ${ }^{\circledR}$ HCV III (Organon Teknika, Holland). Alanine aminotrasferase (ALT) was assayed using a colorimetric procedure (Labtest Diagnostica, Brazil) and the upper normal threshold was $33 \mathrm{UI} / \mathrm{ml}$. HCV-RNA was detected in sera samples using an RT-nested PCR, with primers derived from 5' non-coding region of $\mathrm{HCV}$ genome. HCV genotyping was performed by restriction fragment length polymorphism analysis (RFLP) and identified according to Simmonds' classification (Simmonds et al. 1993). For ISH, probe was obtained by extraction of HCV RNA from serum samples of each patient (Quiagen) following for cDNA syntesis, using a negative-sense primer $-5^{\prime}$ UTR $\mathrm{HCV}$ region (5' ggT gCA Cgg TCT Acg AgA CC 3'). After cDNA was amplified by nested PCR using a set 18 to 36 (5' ggC gAC ACT CCA CCA TRR AT 3') and anti-sense synthetic oligonucleotides, 322 to 343 ( $5^{\prime}$ ggT gCA Cgg TCT Acg AgA CC $3^{\prime}$ ). For the nested PCR inner primers were: sense, 38 to 57 (5' ACC ATR RAT CAC TCC CCT gT 3') 
and antisense, 288 to 308 (5' CAA gCA CCC TAT Cag gCA T 3'). The PCR consisted of 30-s denaturation step $\left(94^{\circ} \mathrm{C}\right)$, a 1-min annealing step $\left(72^{\circ} \mathrm{C}\right)$. Both PCR procedures were similar, except for the 25 consecutives cycles used in the nested. The amplified DNA was labeled with digoxigenin dNTPs during the nested PCR and the efficiency of this procedure confirmed by dot blot hybridization. The liver sections were deparaffinized in xylene and rehydrated in alcohol series. The optimal condition for the enzymatic digestion of liver sections was the use of proteinase $\mathrm{K}$ at concentration of $40 \mu \mathrm{g} / \mathrm{ml}$ in Tris- $\mathrm{HCl} \mathrm{pH}$ 8.0, $1 \mathrm{mM}$ EDTA(TE), followed by an incubation of $20 \mathrm{~min}$ at $37^{\circ} \mathrm{C}$ (Lau \& Davis 1994). Liver sections were then washed with sterile water and a second fixation was carried out in a 4\% paraformaldehyde/PBS for $5 \mathrm{~min}$. After dehydration, sections were immersed into a solution containing $0.25 \%$ acetic anhydrous and $0.1 \mathrm{M}$ triethane $(\mathrm{pH}$ 8.0 ), during $10 \mathrm{~min}$. Finally, sections were incubated in a pre-hybridization solution $(5 \times \mathrm{SSC}$; $1 \times$ Denhardt's solution; $10 \%$ dextran sulfate; $1 \mathrm{mg} / \mathrm{ml}$ herring sperm DNA (Roche); $300 \mathrm{mM} \mathrm{DTT;} 0.05 \mathrm{M}$ Tris; 5 mM EDTA; $600 \mathrm{mM}$ $\mathrm{NaCl}, 50 \%$ deionized formamide and $0.1 \% \mathrm{NaCl}$ ). Each liver biopsy was, then, hybridized with its respective blood derived HCV probe. Hybridization was performed using probe in a pre-hybridization solution. The probes were previously heated at $95^{\circ} \mathrm{C}$ for 5-10 min and submitted to a fast cooling on ice. Then the liver sections were incubated with hibridization solution. Distincts hybridization temperatures $\left(37,39,42\right.$, and $\left.45^{\circ} \mathrm{C}\right)$ and probe concentrations $(0,5$ and $1 \mu \mathrm{g} / \mathrm{ml})$ were tested on liver sections. The most consistent results were found with $0,5 \mu \mathrm{g} / \mathrm{ml}$ of the hybridization buffer at $42^{\circ} \mathrm{C}$ overnight. After hibridization, stringent washings eliminated nonspecific binding. Different conditions of concentration and periods of incubation were tested. The best were $2 \times \mathrm{SSC} / 30 \%$ formamide twice for $10 \mathrm{~min}$ and $1 \times \mathrm{SSC}$ twice for $10 \mathrm{~min}$.

Immunodetection method was carried out following the manufacturer's instructions (DIG DNA Labeling and Detection - Roche, US). Labeling was performed with the substrate nitroblue tetrazolium (NBT-BCIP- Roche, US). The sections were washed with water and counterstained using methyl green. The image capture of ISH in liver sections was obtained by Leitz Dialux microscope. The images were acquired using a video camera-Sony $\mathrm{XC}-003 \mathrm{P}$ $>52(\mathrm{H} \mathrm{X} 582 / \mathrm{V})$ - Leica DMRXA - Leica QWIN standard. Liver biopsies from patients chronically infected with hepatitis B virus (HBV) were used as negative tissue controls. A specific probe for dengue virus also was used for checking the specificity and, finally, pre-hybridization solution without probes was also used, in order to exclude the possibility of non-specific reaction.

A status compatible with chronic hepatitis $\mathrm{C}$ infection for 14 patients was investigated. The Table shows the results for anti-HCV against different $\mathrm{HCV}$ antigens, HCVRNA in serum and liver, the genotypes of HCV, ALT levels and histological finding of these patients. ALT levels were normal in 4 patients, altered from 34 to 89 UI/ML in 8 patients and above $100 \mathrm{UI} / \mathrm{ML}$ in 2 patients.

HCV RNA was detected in all serum samples. Genotyping by RFLP was performed in all of them, showing a high percentage of HCV genotype $1(71.4 \%)$, followed by genotype $3(21.4 \%)$, and genotype $2(7.2 \%)$.

TABLE

Specific anti-HCV (hepatitis C virus) reaction against different HCV antigens, presence of HCV- RNA in serum and liver, alanineaminotransferase (ALT) values, and histological findings among chronically infected hepatitis C patients

\begin{tabular}{|c|c|c|c|c|c|c|c|c|c|c|c|c|c|}
\hline \multirow[b]{2}{*}{ Sample } & \multirow[b]{2}{*}{$\begin{array}{l}\text { Gender } \\
\text { lage }\end{array}$} & \multirow{2}{*}{$\begin{array}{l}\text { ELISA }^{a} \\
\text { DO/CO }\end{array}$} & \multicolumn{6}{|c|}{ Imunoblot ${ }^{b}$} & \multicolumn{5}{|c|}{$\begin{array}{l}\text { Biochemical values, } \\
\text { viral status, and histological findings }\end{array}$} \\
\hline & & & Core1 & Core2 & E2NS1 & NS3 & NS4 & NS5 & ALT & $\begin{array}{l}\mathrm{HCV} \\
\mathrm{RNA}\end{array}$ & Genotype $^{c}$ & ISH & $\mathrm{SCH}$ \\
\hline $\mathrm{P} 1$ & $\mathrm{~F} / 46$ & 9,45 & $2+$ & $1+$ & - & $4+$ & $3+$ & $3+$ & 48 & + & 3 & - & Minimal \\
\hline $\mathrm{P} 2$ & M/68 & 8,60 & $3+$ & $2+$ & - & $2+$ & $3+$ & $2+$ & 89 & + & 1 & + & Mild \\
\hline $\mathrm{P} 3$ & $\mathrm{~F} / 50$ & 10,57 & $2+$ & $1+$ & $2+$ & $4+$ & $4+$ & $3+$ & 26 & + & 1 & + & Minimal \\
\hline $\mathrm{P} 4$ & $\mathrm{M} / 42$ & 9,48 & $2+$ & $2+$ & $1+$ & $1+$ & $1+$ & $1+$ & 34 & + & 1 & + & Mild/moderate \\
\hline P6 & $\mathrm{M} / 44$ & 10,58 & $3+$ & $3+$ & - & $3+$ & - & $3+$ & 265 & + & 2 & + & Moderate \\
\hline P7 & $\mathrm{M} / 38$ & 10,33 & $3+$ & $4+$ & $2+$ & $2+$ & $3+$ & $3+$ & 68 & + & 3 & - & Mild \\
\hline P9 & $\mathrm{M} / 40$ & 10,20 & $3+$ & $1+$ & $2+$ & $4+$ & $1+$ & - & 20 & + & 1 & + & Mild \\
\hline P10 & $\mathrm{M} / 38$ & 9,15 & $3+$ & $2+$ & $1+$ & $1+$ & $4+$ & $2+$ & 43 & + & 1 & + & Mild \\
\hline $\mathrm{P} 12$ & M/67 & 10,55 & $2+$ & $1+$ & $1+$ & $3+$ & $2+$ & - & 66 & + & 1 & + & Moderate \\
\hline P13 & $\mathrm{F} / 56$ & 10,83 & $2+$ & $2+$ & $1+$ & $1+$ & $3+$ & - & 51 & + & 3 & - & Mild \\
\hline P14 & $\mathrm{F} / 60$ & 10,39 & $2+$ & $2+$ & $3+$ & $3+$ & $4+$ & $3+$ & 23 & + & 1 & + & Mild \\
\hline P15 & $\mathrm{M} / 38$ & 10,02 & $3+$ & $2+$ & - & $3+$ & $2+$ & $1+$ & 116 & + & 1 & + & Mild \\
\hline P16 & $\mathrm{M} / 23$ & 10,39 & $2+$ & $2+$ & $1+$ & $2+$ & $3+$ & $3+$ & 33 & + & 1 & - & Minimal \\
\hline P17 & $\mathrm{M} / 49$ & 9,65 & $2+$ & $1+$ & - & $3+$ & $1+$ & $2+$ & 80 & + & 1 & - & Mild \\
\hline
\end{tabular}

$a$ : ELISA for anti-HCV detection (UBI HCV EIA 4.0, United Biomedical Inc., US); DO: optical density at 492 nm; CO: cut-off 0.224; $b$ : immunoblot assay Lia-tek ${ }^{\circledR}$ HCV III (Organon Teknika, Holland) considering grade negative (-) to 4+ according to intensity of reaction as described in manufacturer's instructions; ALT (Labtest Diagnostica, Brazil), normal value 33 UI/ML; HCV-RNA in serum detected by RT-nested PCR using primers that derived from 5' UTR of HCV genome; $c$ : HCV genotypes were determined by RFLP in PCR products that derived from HCV 5'UTR region using Ava II and Rsa I (Life Technologies, US); ISH: in situ hybridization in liver biopsies using 5'UTR that derived probes from HCV genome; SCH: severity of chronic hepatitis: classification according to semi quantitative score. 
The necroinflammatory activity was detected in all liver sections, ranging from minimal to moderate score, however, with no incidence of liver fibrosis or cirrhosis.

HCV genome was identified in 9 out of 14 patients $(64.2 \%)$. The viral genome was detected in isolated cells as hepatocytes, mononuclear, Kupffer, and sinusoidal cells by optical microscopy. However, HCV RNA was present in a lower frequency. The localization of ISH signals was citoplasmatic or perinuclear (Figure). The positive sinusoidal and mononuclear cells was scatter distributed in the lobule, most of them citoplasmatic and rarely associated with necroinflamatory lesions, as described by some authors (Walker et al. 1998). Comparing results between HCV-RNA detection in serum and liver by RT-PCR and ISH, respectively, a lower sensitivity of the second method was observed. This could be expected since ISH does not include amplification of viral genome. The limit of tissue HCV RNA detection estimated by cell culture assay was $14 \pm 2$ genomic equivalents of $\mathrm{HCV}$ positive strand per
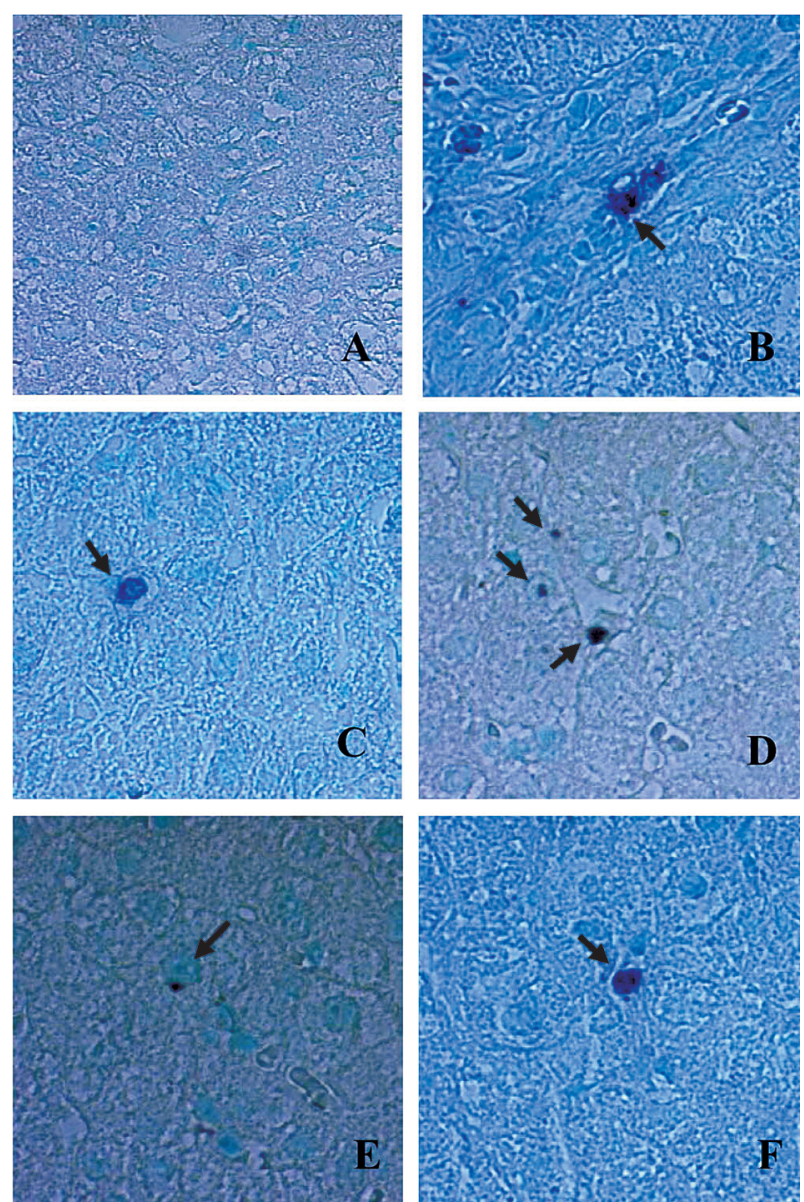

Liver sections from chronically hepatitis $\mathrm{C}$ virus (HCV) infected patients. HCV RNA was detected by in situ molecular hybridization, using specific probe from HCV 5' non-coding region (280 bp). The positive cells were reveled by alcaline phosphate and counterstained by $0.1 \%$ methylgreen. A: non-labeled section using dengue viral probe; B: HCV RNA in mononuclear cell infiltration $(400 \times)$; : perinuclear localization of HCV RNA $(400 \times)$; D: HCV RNA in three different liver cells $(400 \times)$; E: hepatocyte shows perinuclear HCV RNA localization; F: classic citoplasmatic localization of $\mathrm{HCV}$ RNA in sinusoidal cell $(400 \times)$. cell (Agnello et al. 1998) or by quantitative PCR, being about 50 genome copies per cell (Höfler 1990). Also, it must be considered the possibility of RNA damage during the several tissue-processing steps (Guerrero et al. 1997). In our protocol, ISH technique allowed detection, in average, of 1 to 4 strong positive fields per liver section, which corresponds to 3 to 4 portal tracts. RodriguesIñigo et al. (1994) reported the percentage ranging from $0.04 \%$ to $83.3 \%$. Furthermore, the frequency of infected cells seems to be correlated with circulating viral load as described in post-transplant recurrent viral hepatitis (Nuovo et al. 2002). The difference between these findings and ours could be attributed to different profile of host intra-hepatic immune response among the studied population (Thimme et al. 2002).

We observed variations in levels of ALT among our patients, still we could not find any relation between ISH and semi quantitative Ishak's score. Indeed, ALT levels below upper limit of normal range can be found in our patients. On the other hand, elevated levels of ALT can also be observed in patients even in the absence of HCVRNA in liver (Morimoto et al. 1997).

The low concentration of HCV RNA has been described in liver parenchyma, suggesting that persistent infection may be caused by low levels of $\mathrm{HCV}$ replication, as observed in both hepatoma cells and in non-cancerous hepatocytes from patients with HCC (Agnello et al. 1998, Ohishi et al. 1999). Furthermore our results show a low frequency of HCV-RNA detected in cells, besides the different patterns of ALT levels and a weak degree of necroinflamatory activity suggest altogether that $\mathrm{HCV}$ cytopathic effect if present, would not be strong enough to kill hepatocytes (Fanning et al. 2001).

HCV RNA detected by ISH was found in 8 out of 10 patients with samples of genotype 1 , in only one case of genotype 2 and in none of the 3 patients of genotype 3 . Our findings were in accordance with previous report on pattern of intra-hepatic viral replication among chronic hepatitis patients. In subjects infected with HCV genotype 3 , the hepatic viral load seems to be lower than the other genotypes (Castillo et al. 2004).

The principal advantage of ISH method consists in demonstrating the viral presence in a target organ mainly in long-standing abnormal results of liver function patients (ALF-EU). Castillo et al. using ISH in formalin fixed biopsies described occult HCV infection in 57 out of 100 patients with elevated liver enzyme levels, who were seronegative for anti-HCV antibodies and for HCV RNA (Morimoto et al. 1997).

The association between histological index activity, serological markers, serum, and liver HCV RNA content could be used to assess the effectiveness of antiviral treatment in chronic hepatitis C (Arrojo et al. 2003) providing a solid basis for diagnosis and control of patients under antiviral therapy.

Finally, ISH performed following the technique described here constitutes a reliable method of $\mathrm{HCV}$ detection and localization of HCV in tissue, since it allows identification of specific regions of the viral genome with high confidence. In this study ISH was less sensitive than HCVRNA detection in serum by PCR, in such way that it could 
not be used as an isolated marker in the molecular diagnosis of HCV. However it may be an important investigative tool to study "serosilent" HCV infection in cryptogenic cases of liver disease as described in blood donors (George et al. 2002), HIV positive individuals (Bassett et al. 1998) and also reported in chimpanzees experimentally $\mathrm{HCV}$ infected (Ishak et al. 1995). Further studies, comprising a larger sample are under development in order to assess possible association between the presence of HCV-RNA in liver and clinical manifestations, histopathological status, viral genotypes, and even in patients without evidence of circulating $\mathrm{HCV}$.

\section{ACKNOWLEDGMENTS}

To Dr Renato S Marchevsky (Laboratório de Neurovirulência, Bio-Manguinhos-Fiocruz) for preparing the images of in situ hibridization, Dr Marize Miagostovitch (Laboratório de Flavivírus, Departamento de Virologia, IOC-Fiocruz) for having kindly donated the dengue probes.

\section{REFERENCES}

Agnello V, Abel G, Knight GB, Muchmore E 1998. Detection of widespread hepatocyte infection in chronic hepatitis C. Hepatology 28: 573-584.

Arrojo IP, Pareja MO, Orta MD, Luque FN, Lamas MC, Gordo FS, Mancha IV 2003. Detection of a healthy carrier of HCV with no evidence of antibodies for over four years. Transfusion 43: 953-957.

Bassett SE, Brasky KM, Lanford RE 1998. Analysis of hepatitis $C$ virus-inoculated chimpanzees reveals unexpected clinical profiles. $J$ Virol 72: 2589-2599.

Castillo I, Pardo M, Bartolome J, Ortiz-Movilla N, RodriguezInigo E, de Lucas S, Salas C 2004. Occult hepatitis C virus infection in patients in whom the etiology of persistently abnormal results of liver-function tests is unknown. $J$ Infect Dis 189: 7-14.

Fanning L, Loane J, Kenny-Walsh E, Sheehan M, Whelton M, Kirwan W, Collins JK 2001. Tissue viral load variability in chronic hepatitis C. Am J Gastroenterol 96: 3384-3389.

George SL, Gebhardt J, Klinzman D, Foster MB, Patrick KD, Schmidt WN, Alden B 2002. Hepatitis C virus viremia in HIV-infected individuals with negative HCV antibody tests. J Acquir Immune Defic Syndr 31: 154-162.

Guerrero RB, Batts KP, Brandhagen DJ, Germer JJ, Perez RG, Persing DH 1997. Effects of formalin fixation and prolonged block storage on detection of hepatitis $\mathrm{C}$ virus RNA in liver tissue. Diagn Mol Pathol 6: 277-281.

Höfler H 1990 Principles of in situ hybridization. In In Situ Hybridization: Principles and Practice, Oxford Science Publications, Oxford University Press, Oxford.

Ishak K, Baptista A, Bianchi L, Callea F, De Groote J, Gudat F, Denk H 1995. Histological grading and staging of chronic hepatitis. J Hepatol 22: 696-699.
John HA, Birnstiel ML, Jones KW 1969. RNA-DNA hybrids at the cytological level. Nature 223: 582-587.

Lau JY, Davis GL 1994. Detection of hepatitis C virus RNA genome in liver tissue by nonisotopic in situ hybridization. J Med Virol 42: 268-271.

Macville MV, Van Dorp AG, Wiesmeijer KC, Dirks RW, Fransen JA, Raap AK 1995. Monitoring morphology and signal during non-radioactive in situ hybridization procedures by reflection-contrast microscopy and transmission electron microscopy. J Histochem Cytochem 43: 665-674.

Morimoto H, Kuroki T, Kobayashi K, Nomura S, Sakurai M 1997. A histopathological study on localization of hepatitis $\mathrm{C}$ virus RNA in liver of chronic hepatitis C. Osaka City Med J 43: 153-171.

Nuovo GJ, Holly A, Wakely P, Jr., Frankel W 2002. Correlation of histology, viral load, and in situ viral detection in hepatic biopsies from patients with liver transplants secondary to hepatitis C infection. Hum Pathol 33: 277-284.

Ohishi M, Sakisaka S, Harada M, Koga H, Taniguchi E, Kawaguchi T, Sasatomi K 1999. Detection of hepatitis-C virus and hepatitis-C virus replication in hepatocellular carcinoma by in situ hybridization. Scand J Gastroenterol 34: 432-438.

Pardue ML, Gall JG 1969. Molecular hybridization of radioactive DNA to the DNA of cytological preparations. Proc Natl Acad Sci USA 64: 600-604.

Qian X, Guerrero RB, Plummer TB, Alves VF, Lloyd RV 2004. Detection of hepatitis $C$ virus RNA in formalin-fixed paraffin-embedded sections with digoxigenin-labeled cRNA probes. Diagn Mol Pathol 13: 9-14.

Rodriguez-Inigo E, Bartolome J, de Lucas S, Manzarbeitia F, Pardo M, Arocena C, Gosalvez J 1994. Histological damage in chronic hepatitis $\mathrm{C}$ is not related to the extent of infection in the liver. Am J Pathol 154: 1877-1881.

Schiff ER, de Medina M, Kahn RS 1999. New perspectives in the diagnosis of hepatitis C. Semin Liver Dis 19 (Suppl. 1): 3-15.

Simmonds P, Holmes EC, Cha TA, Chan SW, McOmish F, Irvine B, Beall E 1993. Classification of hepatitis C virus into six major genotypes and a series of subtypes by phylogenetic analysis of the NS-5 region. J Gen Virol 74: 2391-2399.

Thimme R, Bukh J, Spangenberg HC, Wieland S, Pemberton J, Steiger C, Govindarajan S 2002. Viral and immunological determinants of hepatitis $\mathrm{C}$ virus clearance, persistence, and disease. Proc Natl Acad Sci USA 99: 15661-15668.

Walker FM, Dazza MC, Dauge MC, Boucher O, Bedel C, Henin D, Lehy T 1998. Detection and localization by in situ molecular biology techniques and immunohistochemistry of hepatitis $\mathrm{C}$ virus in livers of chronically infected patients. $J$ Histochem Cytochem 46: 653-560. 